\title{
UJI AKTIVITAS ANTIBAKTERI EKSTRAK KULIT BUAH MANGGIS (Garcinia mangostana L.) TERHADAP BAKTERI Klebsiella pneumonlae
}

\author{
Brando Melkianus $^{1}{ }^{\text {) }}$, Fatimawali $^{1)}$, Sri Sudewi ${ }^{\text {1) }}$ \\ ${ }^{1)}$ PS. Framasi FMIPA Unsrat Manado, 95115
}

\begin{abstract}
Research has been carried out on the Antibacterial Activity Test of Mangosteen (Garcinia mangostana L.) Fruit Bark Extract against Klebsiella pneumoniae bacteria. This study aims to determine the antibacterial activity of mangosteen peel extract using the diffusion method with positive control of Ciprofloxacin and negative control of aquades and the test solution used by mangosteen peel extract. The result showed differences in extract concentrations of $25 \%(6.66 \mathrm{~mm})$ categorized as medium, extract concentractions of $50 \%(8.83 \mathrm{~mm})$ categorized as medium, extract concentractions of $75 \%(9.16 \mathrm{~mm})$ categorized as medium, and extract concentractions of $100 \%(10.16 \mathrm{~mm})$ categorized as strong in influencing the inhibition of the growth of Klebsiella pneumoniae bacteria. The result of this study also showed that mangosteen peel extract (Garcinia mangostana L.), has a broad-spectrum bioactive compound which means it can inhibit the growth of Gram negative bacteria.
\end{abstract}

Keywords : Garcinia mangostana L, Klebsiella pneumoniae, Ciprofloxacin

\begin{abstract}
ABSTRAK
Telah dilakukan penelitian tentang Uji Aktivitas Antibakteri Ekstrak Kulit Buah Manggis (Garcinia Mangostana L.) Terhadap Bakteri Klebsiella Pneumoniae. Penelitian ini bertujuan untuk mengetahui aktivitas antibakteri ekstrak kulit buah manggis menggunakan metode difusi agar dengan kontrol positif Ciprofloxacin dan kontrol negatif aquades serta larutan uji yang digunakan ekstrak kulit buah manggis. Hasil penelitian menunjukkan Perbedaan konsentrasi ekstrak 25\% (6,66 mm) termasuk sedang, konsentrasi ekstrak 50\% (8,83 mm) termasuk sedang, konsentrasi ekstrak $75 \%(9,16 \mathrm{~mm})$ termasuk sedang, dan konsentrasi ekstrak $100 \%(10,16 \mathrm{~mm})$ termasuk kuat dalam mempengaruhi penghambatan pertumbuhan bakteri Klebsiella Pneumoniae. Hasil penelitian ini juga menunjukan bahwa Ekstrak kulit buah manggis (Garcinia Mangostana L.), memiliki senyawa bioaktif dengan spektrum luas artinya dapat menghambat pertumbuhan bakteri Gram negatif.
\end{abstract}

Kata kunci : My Garcinia Mangostana L, Klebsiella Pneunoniae, Ciprofloxacin 


\section{PENDAHULUAN}

Kesehatan adalah keadaan sejahtera dari badan, jiwa dan sosial yang memungkinkan setiap orang hidup produktif secara sosial dan ekonomis, dimana saat ini tingkat kesehatan menghadapi tantangan yang sangat berat (Nurwidodo, 2006). Masalah kesehatan adalah masalah kompleks yang merupakan hasil dari berbagai masalah lingkungan yang bersifat alamiah atau buatan manusia. Datangnya penyakit merupakan hal yang tidak biasa ditolak ataupun dihindari (Foster, 2006).

Infeksi saluran pernafasan merupakan penyakit yang umum pada manusia. Secara umum penyebab dari infeksi saluran pernafasan terdiri dari berbagai mikroorganisme, namun yang terbanyak akibat infeksi virus dan bakteri. Infeksi saluran pernafasan berdasarkan wilayah infeksinya terbagi menjadi infeksi saluran pernafasan atas (ISPA) dan infeksi pernafasan bawah atau Lower Respiratory Tract Infection (LRI/LRTI) (Depkes RI, 2005). Secara umum penyebab dari infeksi saluran pernapasan adalah berbagai mikroorganisme, diantaranya akibat infeksi bakteri. Salah satu bakteri penyebab bronkitis yaitu Klebsiella pneumoniae (Ikawati, 2011).

Pengobatan klinis untuk menangani penyakit infeksi yaitu dengan penggunaan antibiotik. Banyaknya jenis pembagian, klasifikasi, pola kepekaan kuman, dan penemuan antibiotika baru seringkali menyulitkan klinisi dalam menentukan pilihan antibiotika yang tepat ketika menangani suatu kasus penyakit infeksi.
Efek samping penggunaan antibiotik dapat berupa reaksi alergi, reaksi idiosinkrasi, reaksi toksik, serta perubahan biologik dan metabolik pada hospes (Setiabudy, 2007). Oleh karena itu, dicari pengobatan maksimal dan alternatif lain seperti bahan alam.

Penggunaan bahan alam kini semakin meningkat pemanfaatannya sebagai bahan dasar pembuatan obat tradisional. Karena obat tradisional banyak digunakan, mudah didapat ekonomis dan memiliki efek samping yang relatif rendah.

Salah satu keanekaragaman hayati yang memiliki potensi untuk di kembangkan sebagai obat tradisional adalah Kulit Buah Manggis (Garcinia mangostana L.). Berdasarkan penelitian yang dilakukan Pasaribu et al,. (2012), ekstrak etanol 96\% kulit buah manggis mengandung senyawa kimia golongan alkaloida, flavonoida, glikosida, saponin, tanin dan steroid/triterpenoid. Menurut (Chaverri et al., 2008), tanaman yang memiliki kandungan senyawa flavonoid dapat menghambat pertumbuhan bakteri. Sehubungan dengan adanya indikasi ekstrak Kulit Buah Manggis (Garcinia mangostana L.) mengandung senyawa flavonoid yang dapat menghambat pertumbuhan bakteri, maka hal ini menarik perhatian peneliti untuk melakukan Uji Aktivitas Antibakteri Ekstrak Kulit Buah Manggis (Garcinia mangostana L.) terhadap bakteri Klebsiella pneumoniae.

\section{METODE PENELITIAN}

Penelitian ini dilaksanakan di Laboratorium Mikrobiologi Farmasi dan 
Laboratorium Farmakognosi dan Fitokimia, Program Studi Farmasi Fakultas MIPA, Universitas Sam Ratulangi Manado pada bulan September - November 2018. Dari larutan stok $100 \%$ dibuat larutan uji 25\%, $50 \%, 75 \%$, dan $100 \%$ dengan cara dipipet $0,5 \mathrm{~mL}, 1 \mathrm{~mL}$, dan $1,5 \mathrm{~mL}$ ekstrak kulit buah manggis dan dicukupkan volumenya hingga $2 \mathrm{ml}$. Nutrient Agar (NA) sebanyak larutan $\mathrm{BaCl}_{2} \cdot 2 \mathrm{H}_{2} \mathrm{O} 1,175 \%$ sebanyak 0,5 $\mathrm{mL}$ dalam Erlenmeyer. Kemudian dikocok sampai terbentuk larutan yang keruh. Kekeruhan ini dipakai sebagai standar kekeruhan suspense bakteri uji. Bakteri uji yang telah diinokulasi diambil dengan jarum ose steril lalu disuspensasikan kedalam tabung berisi $2 \mathrm{~mL}$ larutan $\mathrm{NaCl} \quad 0,9 \%$ hingga diperoleh kekeruhan yang sama dengan standar kekeruhan Mc. Farland. Lapisan dasar dibuat dengan cara tuangkan NA $15 \mathrm{~mL}$ kedalam 3 cawan petri untuk lapisan dasar setelah lapisan pertama memadat pada permukaan lapisan dasar diletakkan 5 pencadang (sumuran) yang diatur sedemikian rupa jaraknya agar daerah pengamat tidak saling bertumbuh, kemudian suspensi bakteri dicampurkan ke dalam media pembenihan NA, setelah itu di tuangkan $15 \mathrm{~mL}$ NA pada setiap cawan petri untuk lapisan kedua. Selanjutnya pencadang (sumuran) diangkat secara aseptik dari cawan petri, sehingga terbentuklah sumur sumur yang akan digunakan dalam pengujian antibakteri. Larutan uji ekstrak kulit buah manggis dengan berbagai konsentrasi $(25,50,75 \%$, dan 100\%); aquades sebagai kontrol negatif; larutan Ciprofloxacin sebagai kontrol positif, masing-masing diteteskan pada sumur yang berbeda sebanyak 50 $\mu 1$. Kemudian cawan petri diinkubasi dalam inkubator pada suhu $37^{\circ} \mathrm{C}$ selama 24 jam. Pengamatan dilakukan setelah 1x24 jam masa inkubasi. Daerah bening merupakan petunjuk kepekaan
0,4 g dilarutkan dalam $20 \mathrm{~mL}$ aquades (20 $\mathrm{g} / 1000 \mathrm{~mL}$ ) menggunakan erlenmeyer. Setelah itu dihomogenkan dengan stirrer diatas pemanas air sampai mendidih. Media dasar dibuat dengan cara ditimbang Nutrient Agar (NA) sebanyak 2 g lalu dilarutkan dalam $200 \mathrm{ml}$ aquades $(20 \mathrm{~g} / 1000 \mathrm{~mL})$ menggunakan erlenmeyer. Larutan $\mathrm{H}_{2} \mathrm{SO}_{4}$ $1 \%$ sebanyak $9,95 \mathrm{~mL}$ dicampurkan dengan bakteri terhadap antibiotik atau bahan antibakteri lainnya yang digunakan sebagai bahan uji yang dinyatakan dengan lebar diameter zona hambat (Vandepitte et al., 2005). Diameter zona hambat diukur dalam satuan milimeter (mm) menggunakan mistar berskala dengan cara diameter keseluruhan dikurangi diameter sumuran $7 \mathrm{~mm}$. Kemudian diameter zona hambat tersebut dikategorikan kekuatan daya antibakterinya berdasarkan penggolongan menurut Davis and Stout

\section{HASIL DAN PEMBAHASAN}

Ekstraksi kulit buah manggis dibuat dengan cara maserasi. Sebanyak 100 gram serbuk simplisia kulit buah manggis dimasukkan ke dalam erlenmeyer, kemudian direndam pelarut etanol 96\% sebanyak 1000 $\mathrm{mL}$ ditutup dengan aluminium foil dan dibiarkan selama 5 hari sambil sesekali diaduk. Setelah 5 hari, sampel yang direndam tersebut disaring menggunakan kertas saring menghasilkan filtrat 1 dan ampas 1. Ampas yang ada kemudian dimaserasi dengan larutan etanol 96\% sebanyak $500 \mathrm{~mL}$, ditutup dengan alumunium foil dan dibiarkan selama 2 hari sambil sesekali diaduk. Setelah 2 hari, sampel tersebut disaring menggunakan kertas saring menghasilkan filtrat 2 dan ampas 2. Filtrat 1 dan 2 digabungkan, lalu dievaporasi menggunakan rotary evaporator, sehingga diperoleh ekstrak kental sebanyak 8 gr yang berwarna merah 
kecoklatan. Menurut Davis and Stout (1971), kriteria kekuatan daya antibakteri yaitu diameter zona hambat $5 \mathrm{~mm}$ atau kurang dikategorikan lemah, zona hambat 5$10 \mathrm{~mm}$ dikategorikan sedang, zona hambat 10-20 mm dikategorikan kuat dan zona hambat $20 \mathrm{~mm}$ atau lebih dikategorikan sangat kuat. Berdasarkan kriteria tersebut, maka daya antibakteri ekstrak kulit buah manggis pada bakteri Klebsiella Pneumoniae dengan konsentrasi ekstrak $25 \% \quad(6,66 \mathrm{~mm})$ termasuk sedang, konsentrasi ekstrak $50 \% \quad(8,83 \quad \mathrm{~mm})$ termasuk sedang, konsentrasi ekstrak $75 \%$ $(9,16 \mathrm{~mm})$ termasuk sedang, dan konsentrasi ekstrak 100\% (10,16 mm) termasuk kuat. Sehingga diketahui bahwa konsentrasi ekstrak 25\%, 50\%, 75\%, dan $100 \%$ merupakan konsentrasi efektif untuk menghambat bakteri Klebsiella Pneumoniae. Menurut Robinson (1995), flavonoid berfungsi sebagai antibakteri dengan cara mengikat protein bakteri sehingga menghambat aktivitas enzim yang pada akhirnya mengganggu proses metabolisme bakteri. Sifat lipofilik flavonoid dapat merusak membran sel bakteri karena membran sel mengandung lipid sehingga memungkinkan senyawa tersebut melewati membran.

\section{KESIMPULAN}

$\begin{array}{rrr}\text { Ekstrak kulit buah } & \text { Manggis } \\ \text { (Garcinia Mangostana } & \text { L.) } & \text { memiliki }\end{array}$ aktivitas sebagai antibakteri terhadap bakteri Klebsiella Pneumoniae. Perbedaan konsentrasi ekstrak 25\% (6,66 $\mathrm{mm})$ termasuk sedang, konsentrasi ekstrak $50 \%$ $(8,83 \mathrm{~mm})$ termasuk sedang, konsentrasi ekstrak $75 \%(9,16 \mathrm{~mm})$ termasuk sedang, dan konsentrasi ekstrak 100\% (10,16 mm) termasuk kuat, mempengaruhi penghambatan pertumbuhan bakteri Klebsiella Pneumoniae, dimana semakin tinggi konsentrasi ekkstrak kulit buah manggis yang diberikan semakin tinggi pula aktivitas penghambatan pertumbuhan bakteri Klebsiella Pneumoniae. Hasil penelitian ini juga disimpulkan bahwa

Ekstrak kulit buah manggis (Garcinia Mangostana L.), memiliki senyawa bioaktif dengan spektrum luas artinya dapat menghambat pertumbuhan bakteri Gram negatif.

\section{DAFTAR PUSTAKA}

Agoes, G. (2007). Teknologi Bahan Alam. Bandung: Penerbit ITB Press

Ajizah, A. 2004. Sensitivitas Salmonella typhimurium Terhadap Ekstrak Daun Psidium guajava L. Bioscientiae.

Anonim. 2000. Parameter Standar Umum Ekstrak Tumbuhan Obat. Jakarta: Direktorat Jendral POM. Hal :7-8; 10-11; 13-17

Anonim, 2007. Farmakologi dan Terapi. Fakultas Kedokteran Universitas Indonesia, Jakarta.

Anonim, 2014. Informasi Spesialis Obat. ISFI: Jakarta.

Bresson, W., dan M.T Borges. 2004. Delivery Methods for Introducing Endophitic Bacteria into Maize. Biocontrol 49: 351-322

Chaverri, J.P., Rodriguez, N.M., Ibarra, M.O., and Rojas, J.M.P. 2008. Medicinal Properties of Mangosteen. Journal Food and Chemical Toxicology. (46): 3227-3239.

Cronquist, A., 1981, An Integrated System of Classification of Flowering Plants, New York, Columbia University Press, 477. 
PHARMACON- PROGRAM STUDI FARMASI, FMIPA, UNIVERSITAS SAM RATULANGI, Volume 8 Nomor 1 Februari 2019

Center of Disease Control and Prevention (2009) Klebsiella pneumonia in Healthcare Setting.

Davis dan Stout, 1971. Disc Plate Method Of Microbiological Antibiotic Essay. Journal Of Microbiology.

Departemen Kesehatan RI. 1985. Cara Pembuatan Simplisia. Departemen Kesehatan RI, Jakarta

Depkes RI, 2005; Undang-Undang Republik Indonesia Nomor : 23 tahun 2005. Tentang Kesehatan; Jakarta; Hal 1. Fisioterapi Indonesia; Jakarta; Hal.5

Departemen Kesehatan RI. 1986. Sediaan Galenik. Departemen Kesehatan RI, Jakarta.

Direktur Jenderal POM. 2000. Parameter Standar Umum Ekstrak Tumbuhan Obat. Departemen Kesehatan RI, Jakarta.

Gandjar, I.G., Abdul, 2008. Kimia Farmasi Analisis. Pustaka Pelajar, Yogyakarta.

Harborne, J.B. 1996. Metode Fitokimia Penuntun Cara Modern Menganalisis Tumbuhan. Bandung ITB .Terjemahan: Kosasih P, Soediro Iwang.

Ikawati, Z., 2011, Penyakit Sistem Pernafasan dan Tatalaksana Terapinya, Bursa Ilmu, Yogyakarta, 37-68.

Jawetz, et al. 2001. Mikrobiologi Kedokteran. Salemba Medika, Jakarta.

Jawetz, et al. 2005. Mikrobiologi Kedokteran. Edisi 1. Salemba Medika, Jakarta.
Lay, B.W. 1994. Analisis Mikroba di Laboratorium. Edisi 1. Raja Grafindo Persada, Jakarta.

Mardiana, Lina, 2011, Ramuan Dan Khasiat Kulit Buah Manggis, Jakarta, Penebar Swadaya

Pasaribu F, Sitorus P. 2012. Uji ekstrak etanol kulit buah manggis Garcinia mangostana L.) terhadap penurunan kadar glukosa darah. Journal of Pharmaceutics and Pharmacology. 1(1):1-Podschun R, Ullmann U. Klebsiella spp. as nosocomial pathogens: epidemiology, taxonomy, typing methods, and pathogenicity factors. Clin Microbiol Rev 1998;11(4):589-603.

Phage Therapy Center (2009), Klebsiela pneumonia.

Pelczar, M, Chan. 1988. Dasar-Dasar Mikrobiologi (Jilid1) Jakarta: UI Press.

Podschum R, Ulmann U. Klebseilla spp. as nosocomial pathoges:epidemiology, taxonomy, typing methods, and pathogenicity factors. Clin Microbiol Rev 1998;11(4):589-603

Poeloengan, Masniari dan Praptiwi. 2010. Uji Aktivitas Antibakteri Ekstrak Kulit Buah Manggis (Garnicia mangostana Linn), (Online), (http://digilib.litbang.depkes .go.id/files/disk1/74/jkpkbppk-gdlgrey-2011-masniaripo-3692manggism-i.pdf), diakses 2 Juli 2012.

Prihatman, K. 2000, Manggis (Garcinia mangostana 1), Kantor Deputi Menegristek Bidang Pendayagunaan dan Pemasyarakatan Ilmu Pengetahuan dan Teknologi BPP Teknologi. Jakarta. 
PHARMACON- PROGRAM STUDI FARMASI, FMIPA, UNIVERSITAS SAM RATULANGI, Volume 8 Nomor 1 Februari 2019

Putra, Sitiatava Rizema. 2012. RahasiaRahasia Keajaiban Kulit Buah Manggis untuk Kesehatan Harian \& Terapi Penyakit Berat. Yogyakarta: DIVA Press.

Robinson, T. 1995. Kandungan Organik Tumbuhan Tinggi. Edisi 6. ITB Press, Bandung.

Schlegel, H. G. 1994. Mikrobiologi Umum. Gadjah Mada University Press, Jogyakarta.

Setiabudy, Rianto. 2007. Farmakologi dan Terapi Edisi 5. Jakarta: Balai Penerbit Fakultas Kedokteran Universitas Indonesia.

Soedibyo, M. 1998. Alam Sumber Kesehatan. Balai Pustaka. Jakarta. Halaman 257-258.

Schunack, W, Mayer, K., dan Haake, M., 1990, Senyawa Obat, diterjemahkan oleh bagian farmakologi FK UNAIR, Edisi II, 187, Gadjah Mada University Press, Yogyakarta.

Suryanto, E. 2012. Fitokimia Antioksidan. Penerbit Putra Media Nusantara. Surabaya.

Suriawiria, Unus. 2005. Mikrobiologi Dasar. Papas Sinar Sinarti: Jakarta.

Syukur dan Hermani. 2001. Budidaya Tanaman Obat Komersial. PT Penebar Swadaya, Jakarta.

Tentang Kesehatan; Jakarta; Hal 1. Fisioterapi Indonesia; Jakarta; Hal.5.

Tjitrosoepomo, G. 1994. Taksonomi Tumbuhan (Spermatophyta). Gadjah Mada University Press. Yogyakarta.

Vandepitte, et al. 2005. Prosedur Laboratorium Dasar untuk Bakteriologis Klinis Edisi 2. Buku Kedokteran ECG, Jakarta. 